\title{
The Concrete proportion design and performance test analysis of slag base cement concrete pavement repair material
}

\author{
Ming $\mathrm{Li}^{1,}$,, $\mathrm{Xi}-\operatorname{lan} \mathrm{Zhi}^{2, \mathrm{~b}}$ \\ ${ }^{1}$ School of civil and architecture engineering,Xi'an technological university,Xi'an 710021, China \\ ${ }^{2}$ Key laboratory for Special area of education department, College of highway, Chang' an \\ University, $\mathrm{Xi}^{\prime}$ an 710064,China \\ aemail:xiaocao477218@126.com, bemail:gl19@chd.edu.cn
}

\begin{abstract}
Keywords: cement concrete pavement; slag base repair material; concrete mix proportion design; repair function; road performance.

Abstract. Due to the influence of repeatedly vehicles load and the environmental periodic variation, cement concrete pavement is damaged regularly and the normal usage of road is influenced seriously. The concrete mix proportion of a new kind repair material of cement concrete - slag base is designed in this paper, and its workability and strength performance is contrasted with the 42.5 ordinary Portland cement concrete. The good repair function and road performance is shown in the result of the test, and this new kind of repair material could meet the road require.
\end{abstract}

\section{Introduction}

Because of the features of high strength and good durability,cement concrete pavement is one of the main type of road and are widely used in our country. But in the course of using, the damage of cement concrete pavement is often happened by the combination of various factors, such as the vehicles load and natural environment, which is lead to the big influence on traffic safety and road life.In order to solve this problem, the traditional repair materials are often used by road maintenance workers for repair. The traditional repair material can play a role,but the damage will be increased by its disadvantages,such as high cost and can't open traffic in a short period of time,which also could produced greater economic losses. Therefore, it has a very important significance to study a new rapid repair material.

\section{Slag base repair material}

Slag base repair material[1,2] is a new repair material for cement concrete pavement and has the advantage of road excellent performance and low cost, which is mainly based on slag and can be double alkali inspired by cement clinker and sodium silicate.Through the orthogonal contrast test research,the best formula of cement concrete pavement repair material mortar is obtained as follows:the fineness of slag is $520 \mathrm{~m}^{2} / \mathrm{kg}$, the fineness and mixed quantity of clinker is $375 \mathrm{~m}^{2} / \mathrm{kg}$ and $15 \%$ respectively,the mixed quantity and modules of sodium silicate is $2 \%$ and 2.6 , water cement ratio is 0.4 . The contrast test result of mortar combination property between slag base repair material mortar and ordinary Portland cement is shown in table $1[3,4]$.

Slag base repair material has the advantage of quick-setting and early strength,but as a repair material for cement concrete pavement,the excellent mortar performance is not enough to fully reflect its repair function.In order to test the concrete performance of slag base repair material,the mix proportion is necessary to design, and the experiment of workability and mechanical properties is tested in the design process. 


\section{The concrete mix proportion and Performance test of repair material}

The concrete mix proportion design method of slag base repair material is based on 《Specification for mix proportion design of ordinary concrete》( JGJ55-2000 )[5], and according to three steps which is include initial mix proportion,benchmark mix proportion and laboratory mix proportion[6,7].

Table 1 contrast test table of mortar combination property between slag base repair material mortar and ordinary Portland cement

\begin{tabular}{|c|c|c|c|c|c|c|c|c|}
\hline $\begin{array}{l}\text { Cement } \\
\text { materials }\end{array}$ & $\begin{array}{c}\text { initial } \\
\text { settin } \\
\text { g time } \\
(\mathrm{h})\end{array}$ & $\begin{array}{l}\text { final } \\
\text { settin } \\
\text { g time } \\
(\mathrm{h})\end{array}$ & $\begin{array}{c}3 \mathrm{~d} \\
\text { rupture } \\
\text { strength } \\
(\mathrm{MPa})\end{array}$ & $\begin{array}{c}3 \mathrm{~d} \\
\text { compressi } \\
\text { ve } \\
\text { Strength } \\
(\mathrm{MPa})\end{array}$ & $\begin{array}{c}28 \mathrm{~d} \\
\text { rupture } \\
\text { strength } \\
(\mathrm{MPa})\end{array}$ & $\begin{array}{c}28 \mathrm{~d} \\
\text { compressi } \\
\text { ve } \\
\text { Strength } \\
(\mathrm{MPa})\end{array}$ & $\begin{array}{c}7 \mathrm{~d} \\
\text { Shrinka } \\
\text { ge rate } \\
(\%)\end{array}$ & $\begin{array}{c}28 d \\
\text { Shrinka } \\
\text { ge rate } \\
(\%)\end{array}$ \\
\hline $\begin{array}{c}\text { Repair } \\
\text { material }\end{array}$ & 0.83 & 2.25 & 8.5 & 24.1 & 11.4 & 40.6 & 0.017 & 0.064 \\
\hline $\begin{array}{c}42.5 \\
\text { magnitud } \\
\text { e cement }\end{array}$ & 4.33 & 6.33 & 5.5 & 23.3 & 8.4 & 43.2 & 0.031 & 0.089 \\
\hline
\end{tabular}

According to the calculate result, the initial mix proportion of slag base repair material is determine as follows:

Repair material: water: fine aggregate: coarse aggregate: admixtures

$$
=337.8: 155.4: 610.2: 1296 \cdot 6: 2.7=1: 0.46: 1.81: 3.84: 0.008
$$

According to the preliminary mix proportion, mixing 10L concrete mixture of repairing material,uses the method of slump instrument to test the slump, the result is 33mm which complies with the design requirements $(30 \mathrm{~mm}-50 \mathrm{~mm})$ and has good cohesiveness, water retentivity and suitable sand ratio.

Plus and minus 0.05 on the base of designed water cement ratio in respectively, include designed water cement ratio,form three kinds of water cement ratio as follows: $0.41,0.46,0.51$, mixing three groups of concrete mixture of repairing material according the three kinds of water cement ratio, made into standard test blocks, maintains it $28 \mathrm{~d}$ under standard conditions, then according to the regulation method makes use of concrete press to test the cube compression strength, the test result as shown in table 2 .

Table 2 strength value of repair material concrete in different water cement ratio

\begin{tabular}{c|ccc}
\hline groups & $\begin{array}{c}\text { water cement } \\
\text { ratio }\end{array}$ & $\begin{array}{c}\text { cement water } \\
\text { ratio }\end{array}$ & $\begin{array}{c}28 \mathrm{~d} \text { cube compression strength } \\
\mathrm{f}_{\mathrm{cu}, 28}(\mathrm{MPa})\end{array}$ \\
$\mathrm{A}$ & 0.41 & 2.44 & 36.4 \\
$\mathrm{~B}$ & 0.46 & 2.17 & 30.4 \\
$\mathrm{C}$ & 0.51 & 1.96 & 27.6
\end{tabular}

According to the test result in the table 2, drew the chart of relationship between $28 \mathrm{~d}$ cube compression strength of repair material and cement water ratio as figure 1 shown. 


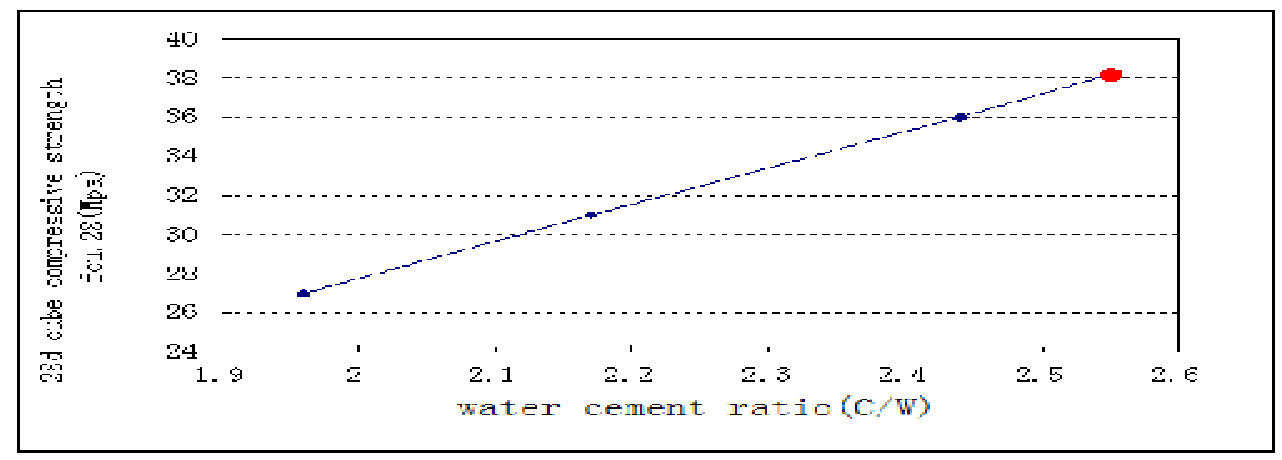

figure 1 the chart of relationship between repair material concrete strength and cement water ratio

By figure 1,due to the compressive strength value of three different cement water ratio are in a straight line shape relations in the chart,may infer the cement water ratio of repair material concrete preparation strength $\mathrm{f}_{\mathrm{cu}, \mathrm{o}}=38.2 \mathrm{MPa}$ is located in the extension point of the straight line, that is $(\mathrm{c} / \mathrm{w}$ ) $=2.55$, mean water cement ratio is 0.40 .

Then get the laboratory mix proportion of repair material concrete is:

Repair material: water: fine aggregate: coarse aggregate: admixtures $=384.6: 153.9: 588.1: 1249.5: 3.09=1: 0.4: 1.53: 3.25: 0.008$

\section{The properties contrast test analysis of slag base repair material and ordinary concrete}

According to the standard,the workability of PO42.5 concrete is tested by the method of slump.

The analysis of workability,cohesiveness and water retention between repair material and PO42.5 cement concrete.(Table 3 )

Table 3 the result of freshly mixed concrete slump test

\begin{tabular}{c|cccc}
\hline gelled material & $\begin{array}{c}\text { Starting slump } \\
\text { value }(\mathrm{mm})\end{array}$ & $\begin{array}{c}\text { Adjusted slump } \\
\text { value }(\mathrm{mm})\end{array}$ & $\begin{array}{c}\text { Water } \\
\text { retentivity }\end{array}$ & $\begin{array}{c}\text { cohesiven } \\
\text { ess }\end{array}$ \\
$\begin{array}{c}\text { repair material } \\
42.5 \text { magnitude }\end{array}$ & 33 & 33 & excellent & excellent \\
Cement concrete & 15 & 31 & good & good
\end{tabular}

According to the slump contrast test data in the table 3 and visual observation shows that, according to the standard( ( JTG F30-2003 ) [8]), the initial slump value of repair material concrete is met the requirements(25-50), so the adjust is not needed.But the initial slump value of PO42.5 is used to adjust.So,the workability of reair material is better than PO42.5.

Then the specimens are made under the three different water cement ratio condition which is $0.47,0.52$ and 0.57 .The specimens is maintained $28 \mathrm{~d}$ under standard conditions, and its compressive strength are tested by the concrete press, the analysis of mechanical properties - 28 days cube compressive strength(table 4).

Table 4 contrast of repairing material concrete strength

\begin{tabular}{c|cc}
\hline test specimen & Water cement ratio & 28d Compressive strength ( MPa ) \\
& 0.41 & 36.4 \\
Repair material concrete & 0.46 & 30.4 \\
& 0.51 & 27.6 \\
42.5 magnitude & 0.47 & 38.5 \\
cement & 0.52 & 30.8 \\
& 0.57 & 27.2
\end{tabular}


According to the strength contrast data in the table 4 shows that under the three different water cement ratio conditions, the strength of slag base repair material is close to the PO42.5 concrete. That shows the repair material has the good repair performance, and could meet the requirements of the road on the aspect of mechanical property.

\section{Mechanism analysis}

Slag base repair material concrete possess the good repair function and road performance, the two main mechanisms as follows.

(1)"Ball effect":The surface area of slag is added by the effect of long time milling, its appearance slowly turn to a circle granular which has a shape advantage,so the "ball effect" is produced.Under the lubrication function of the "ball effect" 's shape advantage, the flowability of concrete is increased[9] in the process of mixing. As well as the area of cohesiveness and water retention, because of the effect of the added high efficiency water reducing agent,the fineness and saturation property of grinding slag are enhanced on a certain extent, and the hydration reaction is turned more favorable, the concrete's cohesiveness is increased and the bad phenomenons such as bleeding,isolation and collapse is inhibited.

(2)Hydration reaction:Similar to the hydration reaction of cement, the hydraulic material which could reinforced concrete of grinding slag is generated in the process of hydration.In addition, because the alkali activator water glass which has dual excitation[10] is added,the depolymerization of slag glass state is accelerated by the $\mathrm{OH}$ - of water glass.And a large amount of water chemical are produced in the reaction of water and silica gel,lead to the dissociation of the slag glass state silicon-oxygen network and the hydration reaction is exacerbated,so the strength of concrete is developed fast and improved remarkable.

\section{Conclusion}

(1)The initial mix proportion,benchmark mix proportion and laboratory mix proportion of slag base repair material concrete is designed successively,the final mix proportion is got as follows:

Repair material: water: fine aggregate: coarse aggregate: admixtures

$$
=384.6: 153.9: 588.1: 1249.5: 3.09=1: 0.4: 1.53: 3.25: 0.008
$$

( 2 ) The good road performance and repair function of slag base repair material concrete is verified by the contrast test of workability and mechanical properties.

(3)The main reason and mechanisms of the good performance of slag base repair material is formed by the grinding slag's "ball effect" and concrete's strengthening effect of hydration reaction.

\section{Acknowledgements}

This work was financially supported by the youth science fund project of education department of Jiangxi province of China (GJJ10278).

\section{References}

[1] Wanliang Zhou,Kunhe Fang:Effect of Slag Content on the Strength of Mortar and Concrete[J]Bulletin of the Chinese Ceramic Society,2012,31(2) : 322-326.In Chinese.

[2] Jiayi Chen,Mingyu Hu,Ye Xiao:Study on Mineral Admixture Concrete Durability under the Complex Environment[J]Bulletin of the Chinese Ceramic Society,2011 , 30(3) : 639-644.In Chinese.

[3] Ming Li:Study on repairing material of cement concrete pavement which based on slag[D]2011.Chang'an university.In Chinese. 
[4] Xiling Zhang,Ailing Yao,Ming Li:Investigation on a Environmental-friendly Repairing Material of Concrete Pavement[J]Bulletin of the Chinese Ceramic Society,2011 , 30(3) : 687-693.In Chinese.

[5] JGJ 55-2000, Specification for mix proportion design of ordinary concrete[S]In Chinese.

[6] JIaji Yan:Road construction materials[M]China communications press,2002 : 95-103.In Chinese.

[7] Aiqin Shen:Cement and concrete[M]China communications press,2004 : 187-194.In Chinese.

[8] JGJ E30-2005, The methods of Cement and Concrete for highway engineering[S]In Chinese.

[9] Chunyi,Yuan,Jiguo Han,Chenglin Shi: Mechanism analysis on the concrete strength and durability of ground granulated blast-furnace slag pavement[J]Science and technology of Jilin communications.2005,1(98) : 14-17.In Chinese.

[10] Baiqian Zhong,Nanru yang:Study on hydration properties of Waterglass - Slag cement.[J]Bulletin of the Chinese Ceramic Society,1994,(3) : 4-8.In Chinese. 